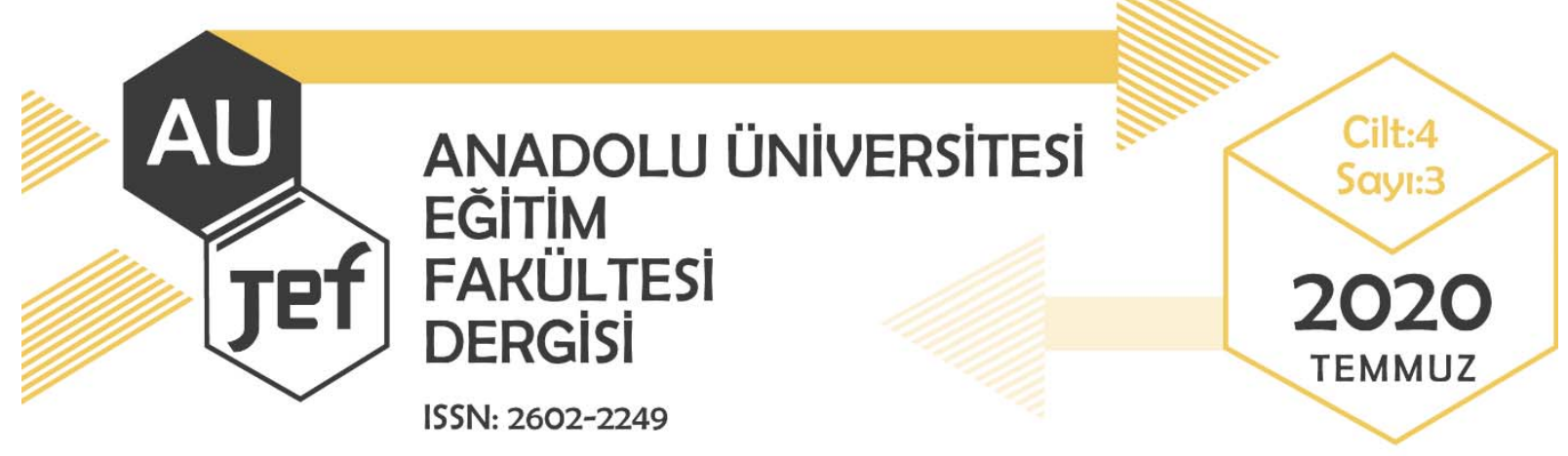

Ses Hakkında Öğrenci Zihinsel Modellerinin Belirlenmesi ${ }^{1}$

\title{
Determination of Student Mental Models About Sound ${ }^{1}$
}

\author{
Mustafa Kemal YÜZBAŞIOĞLU \\ Mehmet Altan KURNAZ ${ }^{3}$
}

Makale Türü: Araştırma Makalesi

Başvuru Tarihi: 10.02 .2020

Kabul Tarihi: 07.07.2020

Atıf İçin: Yüzbaşığlu, M. K. ve Kurnaz, M. A. (2020). Ses hakkında öğrenci zihinsel modellerinin belirlenmesi. Anadolu Üniversitesi Ĕ̈itim Fakültesi Dergisi (AUJEF), 4(3), 254-275.

ÖZ: Bu araştırmanın amacı, ilköğretim sekizinci sınıf öğrencilerinin sesin oluşumu, iletimi, işitilmesi ve yansıması konularıyla ilgili öğrenci zihinsel modellerini belirlemek ve belirlenen zihinsel modellerden hareketle öğrencilerin ses konusundaki genel zihinsel modellerini ortaya çıkarmaktır. Araştırma özel durum çalışması şeklinde yürütülmüştür. Veri toplama aracı, sesin oluşumundan dört, iletiminden altı, işitilmesinden beş ve yansımasından on soru olmak üzere toplam 25 sorudan oluşmaktadır. Veri toplama aracı, Kastamonu il merkezinde yer alan okullar arasından rastgele seçilen beş farklı okuldaki toplam 416 sekizinci sınıf öğrencisine uygulanmıştır. Katılımcı öğrencilerin sorulara vermiş olduğu cevaplar, sözel ve görsel olmak üzere iki ayrı gruba ayrılarak analiz edilmiştir. Bulgular incelendiğinde, öğrencilerin ses konusunda sahip oldukları zihinsel modellerin ağırlıklı olarak 'Bilimsel Model' olduğu tespit edilmiştir. Çalışma sonunda, öğrencilerin genel zihinsel modellerinin yeterli seviyede olduğu sonucuna varılmıştır. Ulaşılan sonuçlardan hareketle, yetersiz zihinsel modellere sahip öğrencilerin eksik algılamaları tamamlamada öğretmenlere ve kitap yazarlarına önerilerde bulunulmuştur.

Anahtar sözcükler: Fen Eğitimi, zihinsel model, ses

\begin{abstract}
The aim of this study is to determine mental models of the eighth-grade students regarding the formation, transmission, hearing and reflection of the sound, and to reveal the general mental models of the students on the basis of the determined mental models. The research was conducted in the form of a case study. The data collection tool consists of a total of 25 questions, four from the formation of sound, six from the transmission, five from hearing, and ten from reflection. The data collection tool was applied to a total of 416 eighth grade students in five different schools randomly selected among the schools in the city center of Kastamonu. The answers given by the participating students to the questions were analyzed by dividing them into two separate groups, verbal and visual. When the findings were examined, it was determined that the mental models that the students had in sound

\footnotetext{
${ }^{1} \mathrm{Bu}$ çalışma birinci yazarın yüksek lisans tezinden hazırlanmıştır.

2 Doktora öğrencisi, Kastamonu Üniversitesi, Fen Bilimleri Enstitüsü, Matematik ve Fen Bilimleri Eğitimi Bölümü, m.kemalyuzbasioglu@gmail.com, ORCID: 0000-0001-8551-2440

3 Prof. Dr., Kastamonu Üniversitesi, Eğitim Fakültesi, Matematik ve Fen Bilimleri Eğitimi Bölümü, altan.kurnaz@gmail.com, ORCID: 0000-0003-2824-4077
} 
were mostly 'Scientific Model'. The study was concluded that the general mental models of the students were at a sufficient level. Based on the conclusions, suggestions were made to teachers and book writers to complete the missing perceptions of students with inadequate mental models.

Keywords: Science education, mental model, sound 


\section{GíRiş}

Birey ve toplumun değişen ihtiyaçları, öğretme-öğrenme teori ve yaklaşımlarında gerçekleşen gelişmeler, bireylerden beklenenleri de etkilemektedir. İçinde bulunduğu çevrede gerçekleşen olayların farkındalığına sahip olmak, insan-çevre arasındaki ilişkileri ve doğayı keşfederek günlük yaşam problemlerine çözüm üretmek de istenilen özellikler arasında sayılabilir (MEB, 2018). Bu bağlamda yaşadığımız çağda doğayı ve çevreyi derinlemesine inceleme noktasında içerisinde barındırdığı sistematik bilgilerden dolayı fen bilimleri önemli rol üstlenmektedir. Bu bilgileri bireylerin edinmesi sürecinde kavramların öğrenenler tarafından yapılandırılması oldukça önemlidir. Bilgilerin bireyler tarafından içselleştirilebilmesi için var olan bilgi ve kavramlarla yeni öğrenilenlerin uyumlu olması ve ezberlenmesi yerine zihinsel süreçlerden geçirilmesi gerekmektedir (Önen, 2005). Bu durum bazı kavramların içeriğinin soyut olmasından dolayı bazen oldukça zor olmaktadır (Greca ve Moreira, 2002). Böyle kavramların içselleştirilmesi bireyler tarafından tam olarak gerçekleştirilemeyebilir (Günbatar ve Sar1, 2005; Ünal ve Ergin, 2006). Bu sebeple öğretme-öğrenme sürecinde soyut kavramların somutlaştırılmasında modeller kullanılabilir (Güneş ve Çelikler, 2010).

NRC'ye (National Research Council) (1996) göre modeller, fiziksel objeler, zihinsel yapılar, matematiksel denklemler, bilgisayar simülasyonları gibi birçok farklı çeşiti olan, gerçek nesneleri, olayları veya olayların sınıflarına karşılık gelen geçici şema ya da yapılardır. Bir olgunun belirli bir yönüne yoğunlaşarak oluşturulan basit temsillerdir (Ingham ve Gilbert, 1991) ve o nesnenin yerine geçerek temsil edilmesini sağlarlar (Nersessian, 1995). Modeller bireylerin farklı alanlardaki bilgileri arasında oluşturulan yapısal haritalardır (Glas, 2002), araştırma, anlama ve düşünmede oldukça önemli rol oynamakta (Harrison ve Treagust, 2000) zihin ile gerçek dünya arasında bağlantı kurulmasını sağlamaktadırlar (Hubber, 2006). Literatüre bakıldığında kavramların öğretimi sürecinde bireylerin anlama seviyelerini artırmak ve zihinlerindeki bilgileri daha anlamlı hale getirmelerine yardımcı olmak amacıyla araştırmacılar model ve modelleme süreçlerinden yararlanmaktadırlar (Birinci ve Apaydın, 2016; Bozdemir-Yüzbaşığlu ve Sarıkaya, 2019; Günbatar ve Sarı, 2005; İyibil ve Sağlam-Arslan, 2010; Jong, 2009; Ünal ve Ergin, 2006). Bu araştırmalara konu olan modellere ilişkin literatürde çeşitli sınıflandırmalar yapılmıştır. Gilbert (2005) modelleri zihinsel, paylaşılan, uzlaşılan, bilimsel ve öğretim modelleri olarak sınıflandırmıştır. Gobert ve Buckley, (2000) zihinsel, kavramsal ve öğretim modelleri olarak gruplandırmıştır. Harrison ve Treagust (2000) ise modelleri; ölçeklendirme modeller, pedagojik analojik modeller, simgesel veya sembolik modeller, matematiksel modeller, teorik modeller, haritalar, diyagramlar ve tablolar, kavram-süreç modelleri, simülasyonlar, senteze dayalı modeller, zihinsel modeller olarak sınıflandırmaktadır. Yürütülen bu çalışmada ise sınıflandırmalar arasında yer alan zihinsel modellere odaklanılmıştır.

Zihinsel modeller bireylerin algılamaları sonucu oluşan ve bilişsel gelişimleri sırasında meydana getirdikleri özel ürünlerdir (Harrison ve Treagust, 1996; Hestenes, 2006). Vosniadou'ya (1994) göre zihinsel modeller bireylerin öğrenilen ya da öğrenilecek olan kavramlarla ilgili ön bilgi yapılarını temsil etmektedir ve bu yüzden öğretim sürecinde dikkate alınmalıdırlar. Zihinsel modellerin bireylerin sahip oluğu içsel yapılar olmaları nedeniyle yürütülen çalışmalarla bu yapılar hakkında bilgiler toplanabilir (İyibil ve Sağlam Arslan, 2010; Kurnaz ve Değermenci, 2012; Kurnaz ve Emen, 2013) ve böylelikle farklı konu ve kavramlar için etkin öğrenme ortamları tasarlanabilir. Yapılan çalışmalar zihinsel modellerin dikkate alındığı öğrenme ortamlarında öğrenmenin daha etkili olduğunu göstermektedir (Bozdemir-Yüzbaşıŏlu ve Sarıkaya, 2019; Güneş ve Çelikler, 2010; Gümüş, vd. 2008; Kurnaz, 2011; Stocklmayer, 2010). Kavram yanılgıları, yanlış inançları ve bilimsel olmayan zihinsel modelleri içerir (Chi, 2013). Bu nedenle araştırmaya konu olan ve literatürde kavramsal anlamlandırmaların tespitine 
(Ayvacı ve Bakırc1, 2018; Beaty, 2000; Bolat ve Sözen, 2012; Demirci ve Efe, 2007; Efe, 2007; Eshach ve Schwartz, 2006; Hrepic, 2002; Merino, 1998; Öztürk ve Atalay, 2012; Zeybek, 2007) ve farkl1 öğrenme ortamlarının öğrenci başarısına etkisine (Atasoy, Tekbıyık ve Gülay 2013; Birinci ve Apaydın, 2016; Dedetürk, Saylan Kırmızıgül ve Kaya, 2020; Kistak, 2014; Kömürkaraoğlu, 2011; Salgut, 2007) yönelik çalışmalarla çeşitli kavram yanılgılarının belirlendiği ses kavramına yönelik zihinsel modellerin tespiti önemli görülmektedir. Buna ek olarak ses konusu fen bilimleri dersi kapsamında öğretilmesiöğrenilmesi zor olan konulardan biri olarak ifade edilmektedir (Atasoy, Tekbıyık ve Gülay, 2013; Bolat ve Sözen, 2012; Demirci ve Efe, 2007; Gök Altun, 2006; Gölgeli ve Saraçoğlu, 2011; Karamustafaoğlu vd, 2010; Kistak, 2014; Kömürkaraoğlu, 2011; Küçüközer, 2009; Okur, 2009; Salgut, 2007). Aynı zamanda ses konusu ortaöğretim ve yükseköğretimde de fizik dersleri kapsamında ele alınmakta ve teknolojik gelişmelerle de günlük yaşantımızda yeri bulunmaktadır. İlgili literatür incelendiğinde ses konusuyla ilgili yürütülen çalışmalarda genellikle öğrencilerin ses konusunda sahip oldukları kavram yanılgılarının ele alındığı saptanmıştır. Öğrenmeyi kolaylaştırma firsatları sunabilen ve öğrencilerin zihinsel yapıları hakkında bilgiler veren zihinsel modellerin yeterince araştırılmadığı tespit edilmiştir. Buradan hareketle ilköğretim öğrencilerinin ses konusuyla ilgili zihinsel modellerini inceleme bu çalışmanın odağı olarak benimsenmiştir.

Araştırmada ilköğretim sekizinci sınıf öğrencilerinin, fen bilimleri dersi ses konusuyla ilgili 'sesin oluşumu, sesin iletimi, sesin işitilmesi ve sesin yansıması' alt konularında sahip oldukları zihinsel modellerin tespit edilmesi ve belirlenen zihinsel modellerden hareketle öğrencilerin ses konusundaki zihinsel modellerini ortaya çıkarılması amaçlanmıştır. Bu amaç doğrultusunda aşağıdaki sorulara cevap aranmıştır:

1. Öğrencilerin 'sesin oluşumu' konusundaki zihinsel modelleri nedir?

2. Öğrencilerin 'sesin iletilmesi' konusundaki zihinsel modelleri nedir?

3. Öğrencilerin 'sesin işitilmesi' konusundaki zihinsel modelleri nedir?

4. Öğrencilerin 'sesin yansıması' konusundaki zihinsel modelleri nedir?

5. Öğrencilerin 'ses' konusundaki genel zihinsel modelleri nedir?

\section{YÖNTEM}

$\mathrm{Bu}$ çalışma özel durum yöntemi ile yürütülmüştür. Özel durum yöntemi, gerçek hakkında derinlemesine bilgi veren, bu gerçeği içinde bulunduğu bağlamla yorumlayan ve araştırılan gerçek hakkında kısa sürede çalışılmasına olanak tanıyan bir araştırma yöntemi olduğundan dolayı (Çepni, 2007) tercih edilmiştir.

\subsection{Araştırmanın Çalışma Grubu}

Araştırma kapsamında amaçlı örnekleme yöntemlerinden biri olan ölçüt örnekleme yönteminden yararlanarak çalışma grubu tespit edilmiştir. Ölçüt örnekleme yönteminde önceden belirlenmiş ölçütler dikkate alınarak çalışma grupları belirlenir (Yıldırım ve Şimşek, 2011). Bu araştırmada belirlenen ölçütler, öğrencilerin sekizinci sınıf olması ve fen bilimleri dersleri kapsamında ses konusuyla ilgili konulara dair öğretim uygulamalarının tamamlanmış olmasıdır. Araştırma, Kastamonu il merkezinde yer alan beş farklı okuldaki toplam 416 sekizinci sınıf öğrencisiyle gerçekleştirilmiştir. 


\subsection{Araştırmada Kullanılan Veri Toplama Aracı}

Öğrencilerin ses konusu ile ilgili sahip oldukları zihinsel modelleri belirlemek için toplam 25 açık uçlu soru kullanılmıştır. Soruların oluşturulması aşaması Şekil 1'de sunulmuştur. Şekil 1'de görüldügüü gibi veri toplama aracının geliştirilmesinde öncelikle fen bilimleri dersi öğretim programında ses konusuna ait kazanımlar detaylı şekilde incelenmiştir. Sonraki aşamada ilgili literatürde zihinsel modellerin nasıl ortaya çıkarıldığı ya da tespit edildiği araştırılmıştır. İlgili öğretim programında hedef kitlenin yaş seviyesinde ses konusunun 'sesin oluşumu', 'sesin iletimi', 'sesin işitilmesi' ve 'sesin yansıması' alt başlıklarına sahip olduğu tespit edilmiştir. Buradan hareketle ilgili literatürde, öğretim programı ve alan uzmanının görüşleri temelinde bir "Öğrenme Durumlarını Belirleme Testi (ÖDBT)" hazırlanmıştır. ÖDBT'nin hazırlanmasında ayrıca zihinsel modelleri belirleme çalışmalarında (Çökelez ve Yalçın, 2012; Demircioğlu, Vural ve Demircioğlu, 2013; Kurnaz ve Değermenci, 2012; Kurnaz ve Emen, 2013, 2014) kullanılan veri toplama araçları incelenerek benzer uygulamalara gidilmiştir.

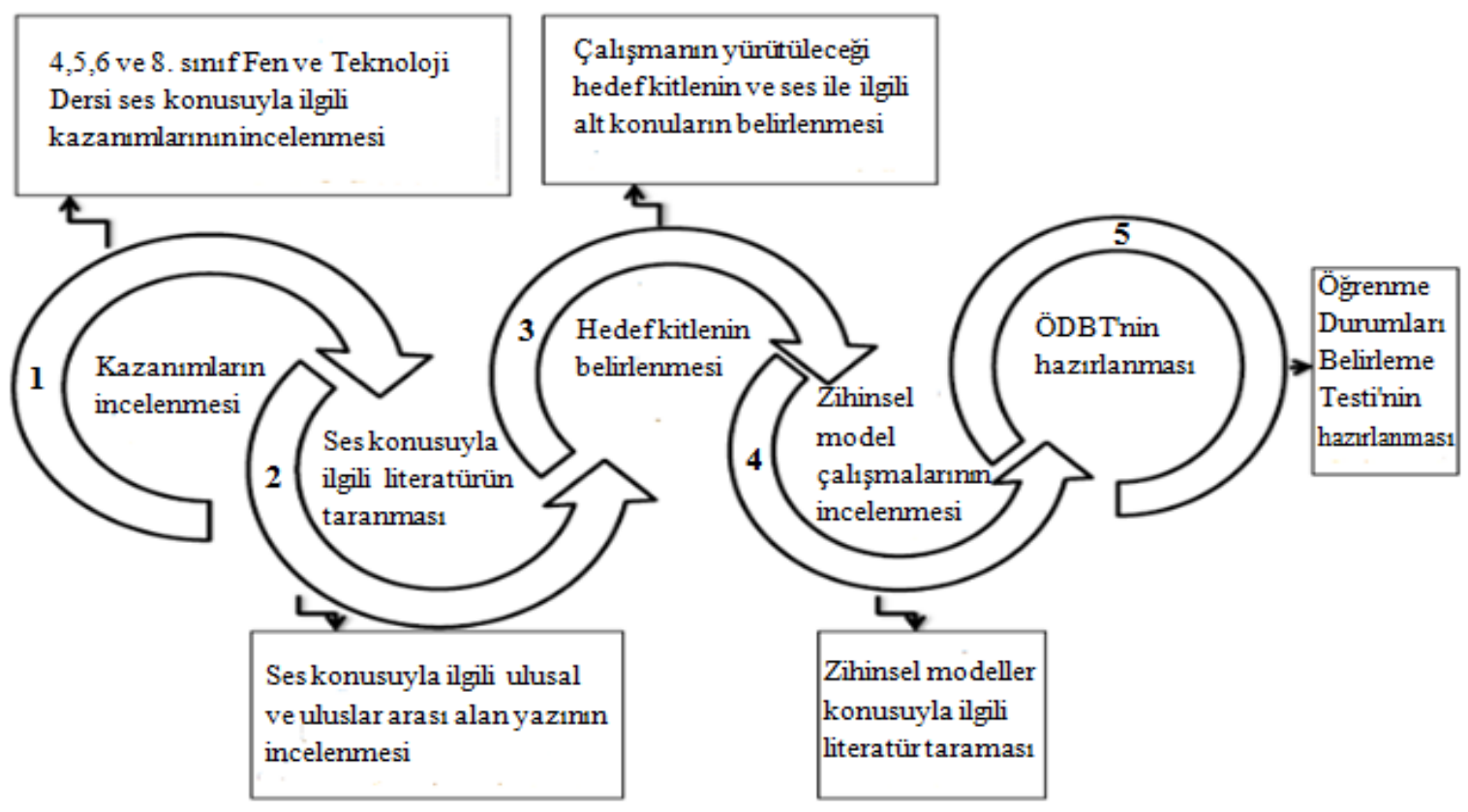

Şekil 1: Veri toplama aracının geliştirilmesi

Oluşturulan sorulara uzman görüşleri doğrultusunda gerekli düzeltmeler yapılmıştır. İlgili düzeltmelerden sonra sorular için pilot uygulama yapılmıştır. Pilot uygulamalar sonrasında soruların okunabilirliği, uygulanabilirliği ve anlaşılabilirliği yönünde analizler yapılmıştır. Yapılan analizler sonrası uzman görüşleri göz önüne alınarak sorulara son şekli verilmiştir. ÖDBT’de yer alan soruların dağılımı Tablo 1'de sunulmuştur.

Tablo 1: ÖDBT'de yer alan soruların dă̆ğlımı

\begin{tabular}{lccc}
\hline \multicolumn{1}{c}{ Konu } & $\begin{array}{c}\text { Görsel } \\
\text { Soruların Sayısı }\end{array}$ & $\begin{array}{c}\text { Sözel } \\
\text { Soruların Sayısı }\end{array}$ & $\begin{array}{c}\text { Toplam } \\
\text { Soru Sayısı }\end{array}$ \\
\hline Sesin Oluşumu & 2 & 2 & 4 \\
Sesin İletimi & 4 & 2 & 6 \\
Sesin İşitilmesi & 2 & 3 & 5 \\
Sesin Yansıması & 5 & 5 & 10 \\
\hline Toplam & 13 & 12 & 25 \\
\hline
\end{tabular}


Tablo 1'de görüldüğü gibi sesin oluşumundan dört, iletiminden altı, işitilmesinden beş, yansımasından 10 tane olmak üzere toplam 25 sorudan oluşan ÖDBT hazırlanmıştır. ÖDBT'de yer alan sorular EK-1'de sunulmuştur.

Veri toplama çalışmalarında öğrencilerin ilköğretim seviyesinde ses konusuyla ilgili son edinimlerini alacakları ünite olan sekizinci sınıf ses ünitesinin okullarda işlenmesi beklenmiş ve ünite konuları tamamlandıktan sonra uygulamalar yapılmıştır. Hazırlanan veri toplama aracı okullardaki sekizinci sınıf öğrencilerine iki ders saati süre verilerek uygulanmıştır. Birinci ders saati kapsamında sesin oluşumu ve iletimi konularıyla ilgili sorular ikinci ders saatinde sesin işitilmesi ve yansıması konularıyla ilgili sorular öğrencilere yöneltilmiştir.

\subsection{Verilerin Analizi}

ÖDBT'de yer alan sorulara verilen cevapların çözümlenmesi sırasında öncelikle Sağlam Arslan ve Devecioğlu (2010), İyibil (2010), Kurnaz (2011), Kurnaz ve Emen (2013, 2014) tarafindan yürütülen öğrenci zihinsel modellerini belirlemeye yönelik çalışmaların analiz yöntemleri incelenmiştir. Daha sonra literatürde yer alan çalışmalardan yola çıkılıp verilerin analizinde benzer uygulamalara gidilmiştir. Araştırmacılar tarafından görüş birliğine varılarak zihinsel modellerin tespiti için öğrencilerin sorulara vermiş olduğu cevaplar sözel ve görsel olmak üzere iki ayrı gruba ayrılarak analiz edilmiştir. Her iki grupta da sorulara öğrencilerin vermiş oldukları cevaplar Tablo 2'deki kriterler göz önüne alınarak tek tek incelenmiştir.

Tablo 2: Sözel/Görsel sorulara verilen cevapların sınıflandırılmasında kullanılan rubrik

\begin{tabular}{|c|c|c|c|}
\hline Nitelik & Kod & Sözel Soru Kriterleri & Görsel Soru Kriterleri \\
\hline $\begin{array}{l}\text { Cevapsiz } \\
\text { Anlamsiz }\end{array}$ & $\mathrm{CA}$ & $\begin{array}{l}\text { Boş bırakılan, belirsiz veya anlaşılmaz } \\
\text { cevaplar }\end{array}$ & Boş bırakılan, belirsiz veya anlaşılmaz çizimler \\
\hline Yanlış & $\mathrm{Y}$ & $\begin{array}{l}\text { Öğrenciler soruya bilimsel olmayan } \\
\begin{array}{l}\text { bilgi(ler) (alternatif } \\
\text { cevaplar vermiştir. }\end{array}\end{array}$ & $\begin{array}{l}\text { Öğrenciler ilgili soruda bilimsel olmayan bilgileri } \\
\text { yansıtacak şekilde çizim(ler) yapmıştır. }\end{array}$ \\
\hline $\begin{array}{l}\text { Kismen } \\
\text { Doğru } \\
\text { Yanlışli }\end{array}$ & KDY & $\begin{array}{l}\text { Öğrenciler soruya kısmen yanlış/alternatif } \\
\text { fikirler içeren cevaplar vermelerine karşın } \\
\text { bazı temel konuları bilmektedirler. }\end{array}$ & $\begin{array}{l}\text { Öğrenciler ilgili soruda bilimsel olmayan bilgileri } \\
\text { yansıtacak şekilde çizim(ler) yapmış olmalarına } \\
\text { rağmen doğru bilgileri yansıtacak çizimlerde } \\
\text { yapmışlardır. }\end{array}$ \\
\hline $\begin{array}{l}\text { Kismen } \\
\text { Doğru } \\
\text { Yanlışsız }\end{array}$ & $\mathrm{KD}$ & $\begin{array}{l}\text { Öğrenciler soruya yanlış/alternatif fikirler } \\
\text { içermeyen ancak temel düzeydeki } \\
\text { bilgilerle cevaplama yapmıştır. }\end{array}$ & $\begin{array}{l}\text { Öğrenciler ilgili soruda yanlış/alternatif fikirleri } \\
\text { içermeyen ancak temel düzeydeki bilgileri yansıtan } \\
\text { çizim(ler) gerçekleştirmiştir. }\end{array}$ \\
\hline Doğru & $\mathrm{D}$ & $\begin{array}{l}\text { Öğrenciler soruya bilimsel (okul bilgisi) } \\
\text { düzeyde cevaplama yapmıştır. }\end{array}$ & $\begin{array}{l}\text { Öğrenciler ilgili soruda bilimsel düzeydeki bilgileri } \\
\text { (okul bilgisi) yansıtan çizim(ler) gerçekleştirmiştir. }\end{array}$ \\
\hline
\end{tabular}

Öğrencilerin çalışma kapsamında kendilerine yöneltilen sorulara verdikleri cevaplar, Tablo 2'de verilen kriterlere göre sesin oluşumu, iletimi, işitilmesi ve yansıması için ayrı ayrı incelenmiş ve sınıflandırılmıştır. Bu sınıflandırmanın ne şekilde gerçekleştirildiğiyle ilgili 310 numaralı öğrencinin sorulara verdiği cevapların sınıflandırması EK-1'de örnek olarak sunulmuştur. 
Öğrencilerin sesin oluşumu, iletimi, işitilmesi ve yansıması ile ilgili görsel/sözel cevapları için anlama seviyeleri ayrı ayrı belirlenmiştir. Yani, anlama seviyeleri tespit edilirken öğrencilerin ilgili ses konusuna ait görsel sorulara verdikleri cevaplar ve sözel sorulara verdikleri cevaplar birbirlerinden bağımsız fakat kendi içlerinde bir bütün olarak incelenmiştir. Örneğin sesin oluşumuyla ilgili öğrencilere yöneltilen iki sözel iki görsel soru vardır. Sözel sorular kendi içinde görsel sorular kendi içinde olacak şekilde bütüncül bir değerlendirme yapılarak anlama seviyeleri değerlendirilmiştir. Bu değerlendirme sürecinde Tablo 3'deki rubriğe göre sınıflandırma yapılmıştır.

Tablo 3: Anlama seviyelerinin belirlenmesinde kullantlan rubrik

\begin{tabular}{|c|c|c|c|c|}
\hline Seviye & Kod & Puan & $\begin{array}{c}\text { Sözel anlama seviyeleri için } \\
\text { açıklama }\end{array}$ & Görsel anlama seviyeleri için açıklama \\
\hline Anlama Yok & {$[\mathrm{AY}]$} & 0 & $\begin{array}{l}\text { Boş bırakılan, belirsiz veya } \\
\text { anlaşı1lmaz cevaplar }\end{array}$ & $\begin{array}{l}\text { Boş bırakılan, belirsiz veya anlaşılmaz } \\
\text { çizimler }\end{array}$ \\
\hline Karmaşık Anlama & {$[\mathrm{KA}]$} & 1 & $\begin{array}{l}\text { Öğrenciler tüm sorulara bilimsel } \\
\text { olmayan bilgiler içeren cevaplar } \\
\text { vermiştir. }\end{array}$ & $\begin{array}{l}\text { Öğrenciler tüm sorularda bilimsel olmayan } \\
\text { bilgileri yansitacak şekilde çizim } \\
\text { yapmıştır. }\end{array}$ \\
\hline $\begin{array}{l}\text { Tamamlanmamış } \\
\text { Anlama }\end{array}$ & {$[\mathrm{TA}]$} & 2 & 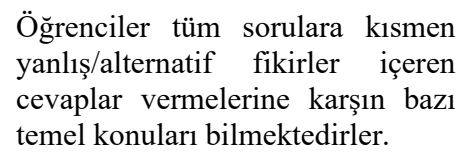 & $\begin{array}{l}\text { Öğrenciler tüm sorularda bilimsel olmayan } \\
\text { bilgileri yansıtacak şekilde çizim(ler) } \\
\text { yapmış olmalarına rağmen doğru bilgiler } \\
\text { yansıtacak çizimlerde yapmışlardır. }\end{array}$ \\
\hline $\begin{array}{l}\text { Kısmen Bilimsel } \\
\text { Anlama }\end{array}$ & $\mathrm{KBA}]$ & 3 & $\begin{array}{l}\text { Öğrenciler tüm sorulara } \\
\text { yanlış/alternatif fikirler içermeyen } \\
\text { ancak temel düzeydeki bilgilerle } \\
\text { cevaplama yapmiştır. }\end{array}$ & $\begin{array}{l}\text { Öğrenciler tüm sorularda yanlış/alternati } \\
\text { fikirleri içermeyen ancak temel düzeydek } \\
\text { bilgileri çizim(ler) } \\
\text { gerçekleştirmiştir. }\end{array}$ \\
\hline Bilimsel Anlama & {$[\mathrm{BA}]$} & 4 & $\begin{array}{l}\text { Öğrenciler tüm sorulara bilimsel } \\
\text { (okul bilgisi) düzeyde cevaplama } \\
\text { yapmıştır. }\end{array}$ & $\begin{array}{l}\text { Öğrenciler tüm sorularda bilimse } \\
\text { düzeydeki bilgileri (okul bilgisi) yansıtan } \\
\text { çizim(ler) gerçekleştirmiştir. }\end{array}$ \\
\hline
\end{tabular}

Öğrenciler kendilerine yöneltilen sesin oluşumu, iletimi, işitilmesi ve yansıması ile ilgili görsel/sözel sorulara verdikleri cevapların sınıflandırılması yapıldıktan sonra, her bir alt konu için belirlenen görsel ve sözel anlama seviyelerinden hareketle öğrenci zihinsel modelleri ortaya çıarılmıştır. Öğrencilerin görsel ve sözel anlama seviyeleri bilimsel nitelikteyse ilgili konu için öğrenci zihinsel modeli "Bilimsel Model" şeklinde belirlenmiştir. Öğrencilerin görsel anlamaları bilimsel ve sözel anlamaları bilimsel olmayan nitelikteyse ilgili konu için öğrenci zihinsel modeli "Görsel Baskın Model" şeklinde belirlenmiştir. Öğrencilerin görsel anlamaları bilimsel olmayan ve sözel anlamaları bilimsel nitelikteyse ilgili konu için öğrenci zihinsel modeli "Sözel Baskın Model" şeklinde belirlenmiştir. Öğrencilerin ses konusuyla ilgili görsel ve sözel anlamaları yetersiz nitelikteyse ilgili konu için öğrenci zihinsel modeli "Uyumsuz Model" şeklinde belirlenmiştir. 
Tablo 4: Öğrenci zihinsel modellerini belirleme rubriğ $i$

\begin{tabular}{cccl}
\hline Puan & Modeller & Anlama Seviyeleri & \multicolumn{1}{c}{ Özellikler } \\
\hline 3 & Bilimsel Model & {$\left[\begin{array}{ll}4 & 3 \\
3 & 4\end{array}\right]$} & $\begin{array}{l}\text { Öğrencilerin ses konusuyla ilgili sözel ve görsel anlama } \\
\text { seviyeleri bilimsel niteliktedir. }\end{array}$ \\
Puan & (BM) & {$\left[\begin{array}{ll}4 & 0 \\
3 & 1\end{array}\right]$} & $\begin{array}{l}\text { Öğrencilerin ses konusuyla ilgili görsel anlamaları bilimsel } \\
\text { sözel anlamaları bilimsel olmayan niteliktedir. }\end{array}$ \\
2 & Görsel Baskın Model & \\
Puan & (GBM) & {$\left[\begin{array}{ll}0 & 4 \\
1 & \\
2 & 3\end{array}\right]$} & $\begin{array}{l}\text { Öğrencilerin ses konusuyla ilgili görsel anlamaları bilimsel } \\
\text { olmayan sözel anlamaları bilimsel niteliktedir. }\end{array}$ \\
2 & Sözel Baskın Model & \\
Puan & (SBM) & {$\left[\begin{array}{ll}0 & 0 \\
1 & 1 \\
2 & 2\end{array}\right]$} & $\begin{array}{l}\text { Öğrencilerin ses konusuyla ilgili görsel ve sözel anlamaları } \\
\text { yetersiz niteliktedir. }\end{array}$ \\
\hline
\end{tabular}

Zihinsel modellerin tespit işlemleri sesin oluşumu, sesin iletimi, sesin işitilmesi ve sesin yansıması konuları için birbirinden bağımsız olarak gerçekleştirilmiştir. Bu işlem yapılırken öğrencilerin görsel ve sözel anlama seviyeleri için belirlenen kodlar kullanılarak matrisler oluşturulmuştur (bkz. Tablo 4).

Öğrencilerin sesin oluşumu, sesin iletimi, sesin işitilmesi ve sesin yansıması konuları ile ilgili görsel ve sözel anlama seviyeleri belirlendikten sonra öğrencilerin sahip oldukları anlama seviye kodlarından yola çıkılmış ve Tablo 4'de verilen rubrikten yararlanılarak öğrenci zihinsel modelleri belirlenmiştir. Bu işlem yapılırken öğrencilerin görsel anlama seviyeleri ve sözel anlama seviyeleri çaprazlanmıştır. Öğrencilerin hem görsel ve hem de sözel anlama seviye kodları 4 veya 3 ise öğrenci zihinsel modeli BM şeklinde sınıflandırılmıştır. Öğrencinin görsel anlama seviyesi kodu 4 veya 3 sözel anlama seviyesi kodu 2, 1 ve 0'dan birisi ise öğrenci zihinsel modeli GBM şeklinde sınıflandırılmıştır. Öğrencinin görsel anlama seviye kodu 2, 1 ve 0 dan birisi, sözel anlama seviye kodu 4 veya 3 ise öğrencinin zihinsel modeli SBM şeklinde sınıflandırılmıştır. Son olarak öğrencinin görsel ve sözel anlama seviye kodu 2,1 ve 0 kodlarından birisi ise öğrenci zihinsel modeli UM şeklinde sınıflandırılmıştır. Örneğin EK-1'te cevapları paylaşılan 310 numaralı öğrencinin sesin oluşumu konusunda, görsel anlama seviyesi BA şeklinde bulunmuş ve kodu 4, sözel anlama seviyesi ise KBA şeklinde bulunmuş ve kodu 3'tür. Rubriğe göre sesin oluşumu konusunda öğrenci zihinsel modeline baktı̆̆ımızda; görsel anlama seviye kodu 4 ve sözel anlama seviye kodu 3 olduğu için 310 numaralı öğrencinin sesin oluşumu konusunda ki zihinsel modeli BM'dir. Yapılan bu işlemler sesin iletimi, işitilmesi ve yansıması konuları içinde tekrarlanmıştır.

Öğrencilerin sesin oluşumu, iletimi, işitilmesi ve yansıması konularında sahip oldukları zihinsel modellerden yola çıkılarak ses konusuyla ilgili genel zihinsel modelleri (GZM) belirlenmiştir. Bu hesaplama sirasında Tablo 4'te belirtildiği gibi, BM'ye sahip öğrencilere 3 puan, GBM'ye sahip öğrencilere 2 puan, SBM'ye sahip öğrencilere 2 puan ve UM'ye sahip öğrencilere ise 1 puan verilmiştir. Tabloda verilen puanlamalardan hareketle sesin oluşumu, iletimi, işitilmesi ve yansıması konuları için belirlenen zihinsel model puanlarından yola çıarak, her öğrenci için bir puan hesaplanmıştır. Puanın hesaplanmasında aritmetik ortalama formülünden yararlanılmıştır. 


$$
G Z M=\frac{Z M 1+Z M 2+Z M 3+Z M 4}{4}
$$

Öğrenciler için belirlenen puanlardan (aritmetik ortalamalardan) ve Vosniadou ve Brewer (1992, 1994)'ın çalışmalarından yararlanarak öğrencilerin ses konusuyla ilgili genel zihinsel modelleri ilkel, sentez ve bilimsel model şeklinde sınıflandırılmıştır (Tablo 5).

Tablo 5: Genel zihinsel modeller

\begin{tabular}{|c|c|c|}
\hline $\begin{array}{l}\text { Genel Zihinsel } \\
\text { Model }\end{array}$ & Puan Aralığı & Özellik \\
\hline Bilimsel Model & $2,34-3,00$ & $\begin{array}{l}\text { Bilimsel bilgilerle (okul bilgisi) örtüşen ve/veya bilimsel nitelikte kabul } \\
\text { edilebilecek durumda olma }\end{array}$ \\
\hline Sentez Model & $1,66-2,33$ & $\begin{array}{l}\text { Bilimsel bilgilerle (okul bilgisi) kısmen örtüşen ancak bilimsel nitelikte kabul } \\
\text { edilemeyecek durumda/yetersizlikte olma }\end{array}$ \\
\hline İlkel Model & $1,00-1,65$ & Bilimsel bilgilerle tamamen örtüşmeme durumunda/yetersizliğinde olma \\
\hline
\end{tabular}

Bir öğrencinin sesin oluşumu, sesin iletilmesi, sesin işitilmesi ve sesin yansıması konularındaki zihinsel modelleri belirlendikten sonra ilgili puanlama ölçütlerine göre GZM hesaplama formülünden öğrencinin GZM'si bulunmuştur. Daha sonra, Tablo 6'da belirtildiği gibi, bir öğrencinin GZM'si 2,343,00 arasındaysa öğrencinin ses konusundaki GZM'si Bilimsel Model, 1,66-2,33 arasında ise öğrencinin ses konusundaki GZM'si Sentez Model ve 1,00-1,65 arasındaysa öğrencinin ses konusundaki GZM'si İlkel Model şeklinde sınıflandırılmıştır. Örneğin, EK-1'te cevapları paylaşılan 310 numaralı öğrencinin sesin oluşumu konusundaki zihinsel model puanı 3, sesin iletimi konusundaki zihinsel model puanı 3 , sesin işitilmesi konusundaki zihinsel model puanı 3 ve sesin yansıması konusundaki zihinsel model puanısa 3'tür. Bulunan bu değerleri GZM formülünde yerine koyduğumuzda aşağıdaki gibi GZM puanı 3 olarak bulunur.

$$
G Z M=\frac{3+3+3+3}{4}=3
$$

Tablo 5 de yer alan sınıflandırma kriterlerine bakıldığında 310 numaralı öğrenci 2,34-3,00 aralığında olduğu için GZM'si Bilimsel Model şeklinde değerlendirilmiştir. Yapılan bu örnek işlem araştırmacılar tarafından ortak görüş uygulama kapsamındaki toplam 416 ilköğretim 8. sınıf öğrencisi için ayrı ayrı gerçekleştirilmiştir.

\section{BULGULAR}

Öğrenciler tarafından ÖDBT'nin içerisinde yer alan sesin oluşumu, iletilmesi, işitilmesi ve yansıması konularıyla ilgili her bir soru için verdikleri cevaplar birbirinden bağımsız olacak şekilde analiz edilmiştir. Uygulamaya katılan her öğrencinin cevapları sesin oluşumu, iletilmesi, işitilmesi ve yansıması konuları için birbirinden bağımsız olarak, sözel ve görsel cevaplar şeklinde Tablo 2' de verilen kriterler göz önüne alınarak sınıflandırılmıştır. Bu sınıflandırma işlemi tamamlandıktan sonra anlama seviyelerinin belirlenmesinde kullanılan rubriğe (bkz. Tablo 3) göre uygulamaya katılan öğrencilerin 
sözel ve görsel anlama seviyeleri belirlenmiştir. Sesin oluşumu, iletimi, işitilmesi ve yansıması konuları için elde edilen öğrenci sözel ve görsel anlama seviyeleri Tablo 6'da sunulmuştur.

Tablo 6: Ses konusu ile ilgili ögrenci sözel ve görsel anlama seviyeleri

\begin{tabular}{ccccccc|ccccc}
\hline & \multicolumn{5}{c}{ Sözel Anlama Seviyeleri } & \multicolumn{5}{c}{ Görsel Anlama Seviyeleri } \\
& & AY & KA & TA & KBA & BA & AY & KA & TA & KBA & BA \\
\hline \multirow{2}{*}{ Sesin Oluşumu } & f & 7 & 44 & 79 & 221 & 65 & 55 & 12 & 6 & 197 & 146 \\
& $\%$ & 1,68 & 10,58 & 18,99 & 53,13 & 15,62 & 13,22 & 2,89 & 1,44 & 47,36 & 35,09 \\
\hline \multirow{2}{*}{ Sesin İletimi } & f & 28 & 18 & 20 & 130 & 220 & 12 & 12 & 7 & 160 & 225 \\
& $\%$ & 6,73 & 4,33 & 4,81 & 31,25 & 52,88 & 2,89 & 2,89 & 1,68 & 38,46 & 54,08 \\
\hline \multirow{2}{*}{ Sesin İşitilmesi } & f & 5 & 5 & 2 & 203 & 201 & 35 & 19 & 15 & 149 & 198 \\
& $\%$ & 1,2 & 1,2 & 0,48 & 48,8 & 48,32 & 8,41 & 4,57 & 3,61 & 35,82 & 47,59 \\
\hline \multirow{2}{*}{ Sesin Yansimasi } & f & 19 & 38 & 1 & 327 & 31 & 23 & 38 & 4 & 291 & 60 \\
& $\%$ & 4,57 & 9,14 & 0,24 & 78,60 & 7,45 & 5,53 & 9,14 & 0,96 & 69,95 & 14,42 \\
\hline
\end{tabular}

Tablo 6 incelendiğinde, sesin oluşumu konusunda öğrencilerin sözel anlama seviyelerinin en büyük kısmının \%53,13 ile KBA kodunda gruplandığı görülmektedir. KA kodlu kategoride \%10,58, TA kodlu kategoride \%18,99 ve BA kodlu kategoride \%15,62 oranında sınıflanmanın olduğu ve yüzdelerin birbirine oldukça yakın olduğu tespit edilmiştir. En düşük anlama seviyesi ise \%1,68 ile AY kodlu anlama seviyesindedir. Sesin oluşumu konusunda öğrencilerin görsel anlama seviyelerinde AY anlama seviyesi \%13,22 olarak tespit edilmiş, en düşük anlama seviyeleri ise \%2,89 KA kodu ve \%1,44 TA kodu olarak tespit edilmiştir. Ayrıca sesin oluşumu konusunda çoğunluğun görsel anlama seviyesinin \%47,36 KBA kodunda ve \%35,09 BA kodunda gruplandığı görülmektedir. Sesin oluşumu konusuyla ilgili örnek öğrenci cevapları Şekil 2'de sunulmuştur.

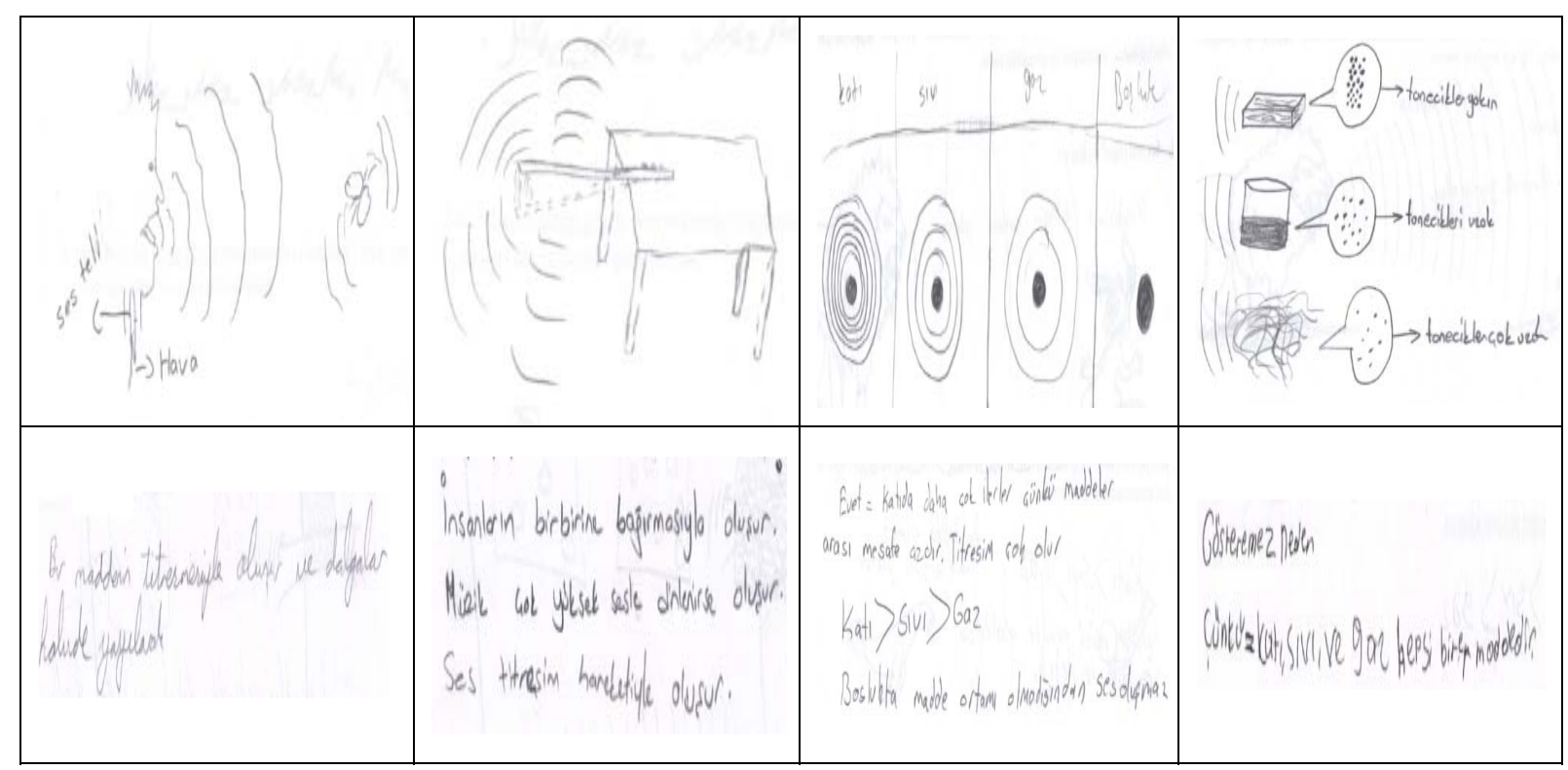

Şekil 2: Sesin Oluşumu konusu ile ilgili örnek öğrenci cevapları 


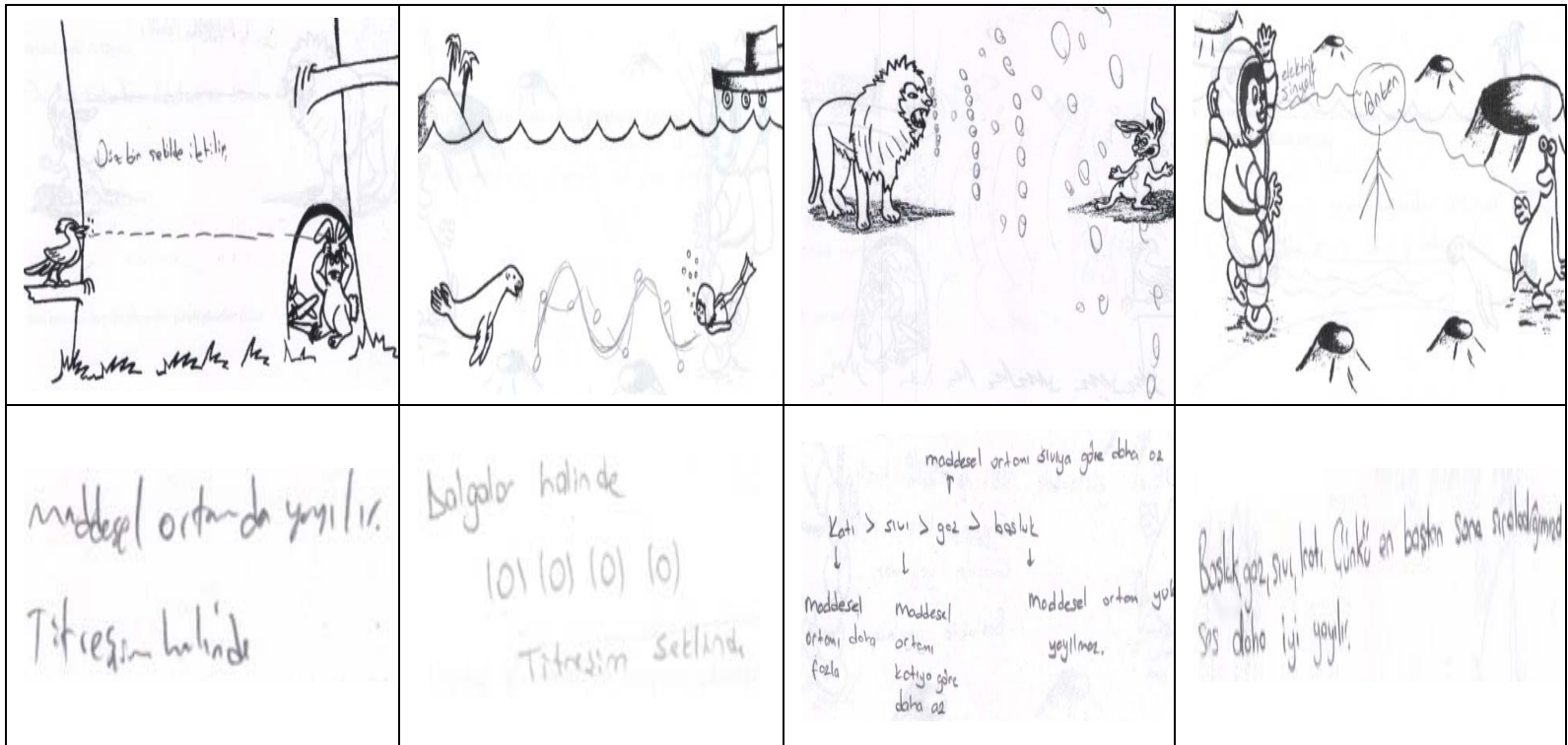

Şekil 3: Sesin İletimi konusu ile ilgili örnek öğrenci cevapları

Tablo 6 incelendiğinde, sesin iletimi konusunda öğrencilerin sözel anlama seviyelerinin en fazla, $\% 52,88$ BA ve \%31,25 KBA şeklinde tespit edildiği görülmektedir. \%6,73 AY, \%4,33 KA ve \%4,81 TA seviyelerinin yüzdelerinin birbirine çok yakın ve düşük olmaları dikkat çeken bir diğer noktadır. Sesin iletimi konusunda öğrencilerin görsel anlama seviyelerinde en fazla kısmının, \%54,08 BA ve \%38,46 KBA şeklinde tespit edildiği görülmektedir. \%2,89 AY, \%2,89 KA ve \%1,68 TA seviyelerinin yüzdelerinin birbirine çok yakın ve düşük olmaları dikkat çekmektedir. Sesin iletimi konusuyla ilgili örnek öğrenci cevapları Şekil 3'te yer almaktadır.

Tablo 6 incelendiğinde, sesin işitilmesi konusunda öğrencilerin sözel anlama seviyelerinin en büyük kısmının, \%48,8 KBA ve \%48,32 BA şeklinde tespit edildiği görülmektedir. \%1,2 AY, \%1,2 KA ve \%0,48 TA seviyelerinin yüzdelerinin birbirine çok yakın ve düşük olmaları dikkat çeken bir diğer noktadır. Sesin işitilmesi konusunda öğrencilerin görsel anlama seviyelerinde en büyük kısmının, $\% 47,59$ BA ve \%35,82 KBA şeklinde tespit edildiği görülmektedir. \%8,41 AY, \%4,57 KA ve \%3,61 TA seviyelerinin yüzdelerinin birbirine çok yakın ve düşük olduğu dikkat çekmektedir. Sesin işitilmesi konusuyla ilgili örnek öğrenci cevapları Şekil 4'de paylaşılmıştır.

\begin{tabular}{|c|c|c|c|}
\hline & 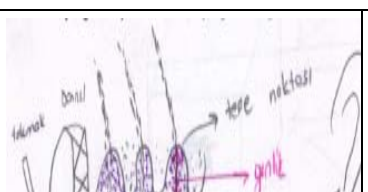 & 影 & El \\
\hline & 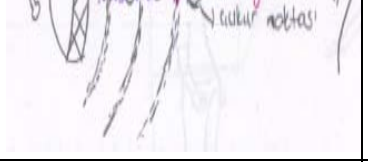 & 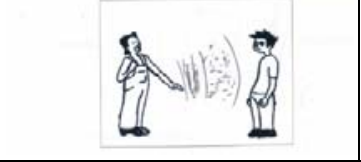 & 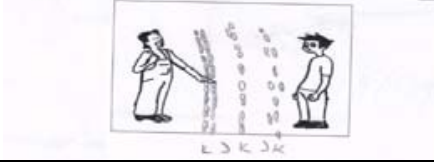 \\
\hline 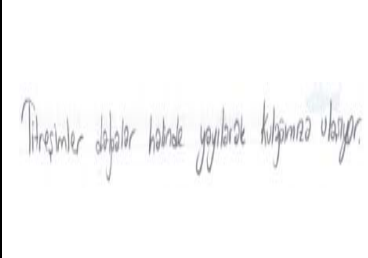 & 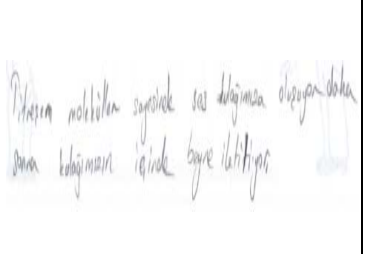 & 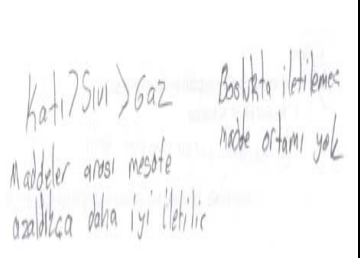 & 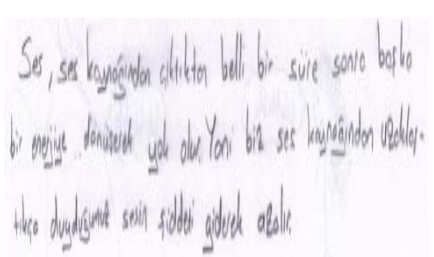 \\
\hline
\end{tabular}

Şekil 4: Sesin İșitilmesi konusu ile ilgili örnek öğrenci cevapları 


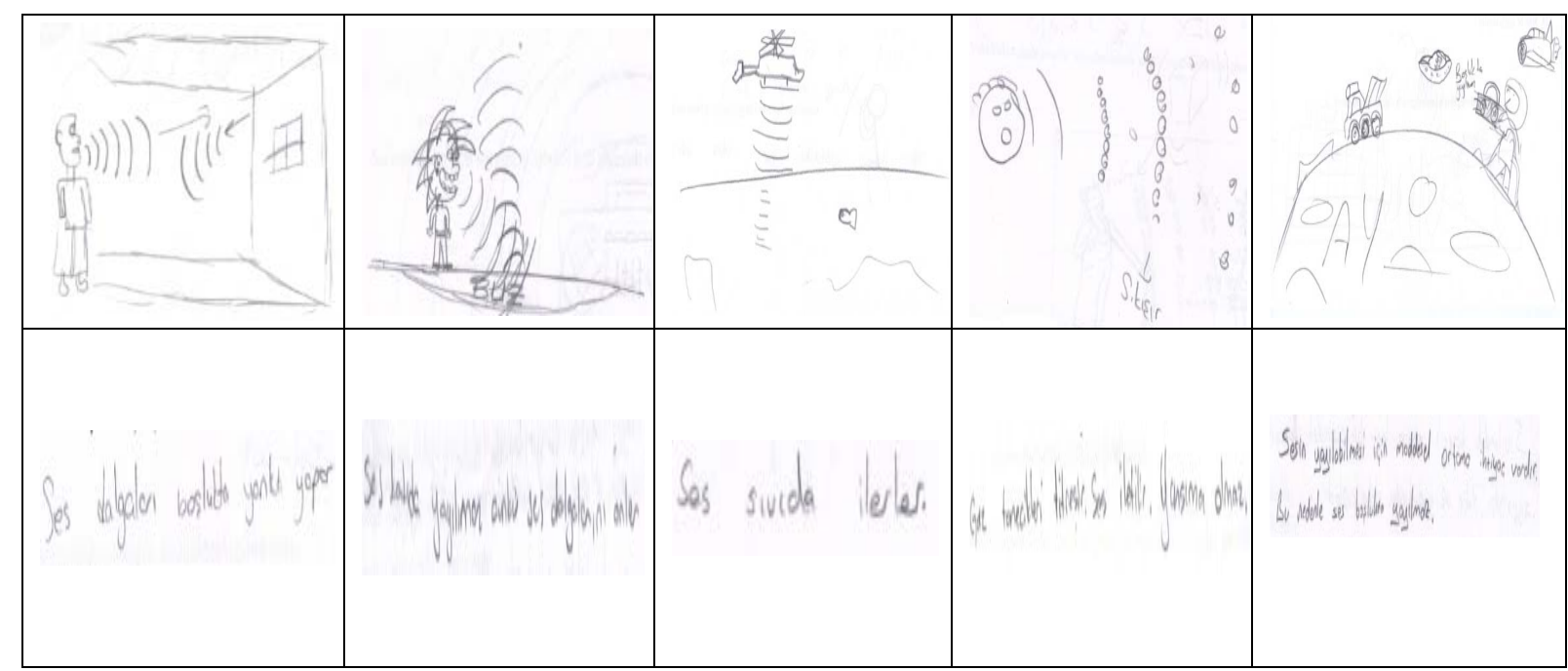

Şekil 5: Sesin Yansıması konusu ile ilgili örnek ögrenci cevapları

Tablo 6 incelendiğinde, sesin yansıması konusunda öğrencilerin sözel anlama seviyelerinde en büyük kısmının, \%78,60 KBA şeklinde tespit edildiği görülmektedir. \%9,14 KA, \%7,45 BA ve \%4,57 AY anlama seviyeleri birbirine yakındır. \%1'lik TA ise en düşük sözel anlama seviyesi olarak tespit edilmiştir. Sesin yansıması konusunda öğrencilerin görsel anlama seviyelerinde en büyük kısmının, \%69,95 KBA şeklinde tespit edildiği görülmektedir. \%14,42 BA, \%9,14 KA, ve \%5,53 AY anlama seviyeleri birbirine yakındır. \%0,96'lık TA ise en düşük görsel anlama seviyesi olduğu dikkat çekmektedir. Sesin yansıması konusuyla ilgili örnek öğrenci cevapları Şekil 5’te sunulmuştur.

Öğrencilerin sesin oluşumu, iletimi, işitilmesi ve yansıması konularıyla ilgili sözel ve görsel anlama seviyelerinden hareketle Tablo 4'de verilen öğrenci zihinsel modellerini belirleme rubriği kullanılarak öğrenci zihinsel modelleri tespit edilmiştir. Öğrencilerin sesin oluşumu, iletimi, işitilmesi ve yansıması konularıyla ilgili tespit edilen zihinsel modelleri Tablo 7'de sunulmuştur.

Tablo 7: Ses konusu ile ilgili ögrenci zihinsel modelleri

\begin{tabular}{cccccc}
\hline & & \multicolumn{4}{c}{ Zihinsel Model } \\
& & UM & SBM & GBM & BM \\
\hline \multirow{2}{*}{ Sesin Oluşumu } & $\mathrm{f}$ & 34 & 42 & 92 & 248 \\
& $\%$ & 8,17 & 10,1 & 22,11 & 59,62 \\
\hline \multirow{2}{*}{ Sesin İletimi } & $\mathrm{f}$ & 21 & 9 & 45 & 341 \\
& $\%$ & 5,05 & 2,16 & 10,82 & 81,97 \\
\hline \multirow{2}{*}{ Sesin İşitilmesi } & $\mathrm{f}$ & 5 & 63 & 7 & 341 \\
& $\%$ & 1,2 & 15,15 & 1,68 & 81,97 \\
\hline \multirow{2}{*}{ Sesin Yansıması } & $\mathrm{f}$ & 26 & 37 & 33 & 320 \\
& $\%$ & 6,25 & 8,89 & 7,93 & 76,93 \\
\hline
\end{tabular}

Tablo 7 incelendiğinde sesin oluşumu konusunda öğrencilerin yarısından fazlasının (\%59,62'sinin) BM zihinsel modeline, yaklaşık dörtte birinin (\% 22,11) GBM zihinsel modeline ve çok az bir bölümünün de SBM $(\% 10,1)$ veya UM $(\% 8,17)$ zihinsel modeline sahip olduğu görülmektedir. 
Sesin iletimi konusunda ise öğrencilerin çok büyük bir kısmının (\%81,97'sinin) BM zihinsel modeline, öğrencilerin bir kısmının (\% 10,82'sinin) GBM zihinsel modeline ve çok az bir bölümünün de UM (\% $5,05)$ veya SBM $(\% 2,16)$ zihinsel modeline sahip olduğu anlaşılmaktadır. Sesin işitilmesi konusunda öğrencilerin çok büyük bir kısmının (\%81,97'sinin) BM zihinsel modeline, öğrencilerin bir kısmının (\% 15,15 'inin) SBM zihinsel modeline ve çok az bir bölümünün de $\operatorname{GBM}(\% 1,68)$ veya UM $(\%$ 1,2) zihinsel modeline sahip olduğu görülmektedir. Sesin yansıması konusunda ise öğrencilerin çok büyük bir kısmının (\%76,93'ünün) BM zihinsel modeline sahip oldukları görülmektedir. Bununla birlikte öğrencilerin $(\%$ 8,89) SBM zihinsel modeline, $(\% 7,93)$ GBM zihinsel modeline, $(\% 6,25)$ UM zihinsel modeline sahip olduğu tespit edilmiştir.

Öğrencilerin sesin oluşumu, sesin iletimi, sesin işitilmesi ve sesin yansıması konularındaki zihinsel modellerinden yola çıkılarak Tablo 5'de verilen puanlamadan faydalanıp öğrencilerin ses konusuyla ilgili genel zihinsel modelleri tespit edilmiştir. Öğrencilerin genel zihinsel modellerinin dağılımı Tablo 8'de verilmiştir.

Tablo 8: Ses konusu ile ilgili ögrenci genel zihinsel modelleri

\begin{tabular}{cccc}
\hline \multirow{2}{*}{ Genel Zihinsel Model } & Puan Aralı̆̆ı & \multicolumn{2}{c}{ Öğrenci Sayısı } \\
\cline { 3 - 4 } & & $\mathbf{f}$ & $\mathbf{\%}$ \\
\hline Bilimsel Model & $2,34-3,00$ & 345 & 82,93 \\
Sentez Model & $1,66-2,33$ & 61 & 14,67 \\
İlkel Model & $1,00-1,65$ & 10 & 2,4 \\
\hline
\end{tabular}

Tablo 8 incelendiğinde ses konusu ile ilgili genel zihinsel modeller arasında en büyük yüzdenin $\% 82,93$ ile bilimsel modele ait olduğu görülmektedir. Sentez model yüzdesi \%14,67 ilkel model yüzdesi ise \%2,4'dür. Bilimsel model yüzdesi ile Sentez ve İlkel model yüzdeleri arasında büyük bir fark olduğu tespit edilmiştir.

\section{TARTIŞMA ve SONUÇ}

Öğrencilerin sesin oluşumu hakkında sözel bilgilerinin bilimsel olarak kabul edilebilecek seviyelerde olduğu ve bu bilgilerini görsel çizimlerle ifade edebildikleri tespit edilmiştir. Atasoy, Tekbıyık ve Gülay (2013)'ın kavram karikatürleri ile yapmış oldukları çalışma sonucunda da bu duruma benzer sonuçlar elde etmişler ve öğrencilerin sesin oluşumundaki temel olayları anladıklarını vurgulamışlardır. Öğrencilerin sesin katı, sıvı, gaz ve boşluk gibi ortamlarda oluşumu hakkındaki görsel cevaplarının sözel karşılıklarını veremedikleri tespit edilmiştir. Çalışma kapsamında elde edilen bulgular incelendiğinde bu durumun, öğrencilerin sesin oluşumunun titreşimle olan bağlantısını kuramamalarından kaynaklandığı düşünülmektedir. İlgili literatür incelendiğinde, Barman ve Miller (1996), Birinci ve Apaydın (2016), Öztürk ve Atalay (2012)'ın çalışmalarında da benzer sonuçlar tespit edilmiştir. Ayrıca öğrencilerin sesin oluşumu ve yansıması olaylarını birbiriyle karıştırdıkları belirlenmiştir ve bu bulgu Efe (2007)'nin yürütmüş olduğu çalışmayla benzerlik göstermektedir. Bu durumların yanı sıra öğrencilerin, insan sesinin ses tellerinin birbirine çarpmasılyla oluştuğunu düşündükleri tespit edilmiş ve literatüre bakıldığında Beaty (2000) ile Demirci ve Efe (2007)'de yürüttükleri çalışmalarda benzer durumları saptamışlardır. Ses konularındaki zihinsel model yüzdelerine 
bakıldığında, öğrencilerin sesin oluşumuyla ilgili öğrenme ortamlarının diğer ses konularındaki öğrenme ortamlarına göre yetersiz olduğu sonucuna varılmıştır. Sesin oluşumu konusunda ilköğretim sekizinci sınıf öğrencilerinin, görsel sorulara verdikleri cevapların çoğunda günlük hayatlarında gördükleri durumları kullandıkları görülmüştür. Bu durum öğrencilerin zihinsel model oluşturma aşamasında çevresindeki olaylardan ve durumlardan doğrudan etkilendikleri sonucunu ortaya koymuştur.

Öğrencilerin sesin iletimi konusundaki görsel ve sözel bilgilerinin birbiriyle örtüşür nitelikte olduğu yapılan çalışma sonucunda tespit edilmiştir. Sesin iletimi konusunda öğrenci başarısı yüksek olmasına rağmen bazı öğrencilerin sesin iletiminde maddesel ortama ihtiyaç duyulmadığını ve sesin katı ortamda yayılamayacağını düşündükleri tespit edilmiştir. Elde edilen bu sonuç alan yazındaki çalışmaları (örn. Bolat ve Sözen, 2012; Demirci ve Efe, 2007; Hrepic, 2002; Kistak, 2014; Küçüközer, 2009; Öztürk ve Atalay, 2012; Sözen ve Bolat, 2014) destekler niteliktedir. Ayrıca bazı bulgulardan hareketle öğrencilerin 'sesin her madde tarafından iletilemeyeceği, tanecikler arası boşlukların arttıkça sesin daha iyi iletilebileceği bu yüzden de sesin boşlukta yayılabileceği' şeklinde okul bilgisinden uzak ve alan yazında yer alan bazı çalışmalarla örtüşen (Barman ve Miller, 1996; Beaty, 2000; Bolat ve Sözen, 2012; Hrepic, 2002; Kistak, 2014; Linder ve Ericson, 1989; Öztürk ve Atalay, 2012) nitelikte algılamalarının olduğu da tespit edilmiştir. Öğrencilerin sesin iletimi konusundaki görsel ve sözel anlama seviyelerinden yola çıkılarak tespit edilen zihinsel modellerine bakıldığında (bkz. Tablo7.), öğrencilerin \%81.97'sinin BM kodlu zihinsel modele sahip oldukları görülmüştür. Bu durumlardan yola çıkılarak öğrencilerin sesin iletimi konusunda, özellikle sesin oluşumu ve sesin yansıması konularına göre daha başarılı oldukları ve öğrencilerin öğretilmek istenen kazanımların çoğunu yapılandırdıkları tespit edilmiştir.

Öğrencilerin sesin işitilmesi konusunda görsel ve sözel anlama seviyelerinin yüksek nitelikte olduğu saptanmıştır. Katılımcıların sesin işitilmesi konusundaki zihinsel modelleri incelendiğinde, sesin iletimi konusuyla birlikte en yüksek BM kodlu zihinsel model sınıflandırma yüzdesinin bu konuda olduğu belirlenmiştir. Sesin işitilmesi konusundaki SBM ise diğer ses konuları içerisinde en yüksek yüzde olarak tespit edilmiştir. Bu sınıflandırmada bulunan öğrencilerin sesin işitilmesi konusundaki sözel bilgilerinin yeterli seviyede olduğu fakat görsel bilgilerinin yetersiz olduğu sonucuna varılmıştır. $\mathrm{Bu}$ durumlardan yola çıkılarak öğrencilerin sesin işitilmesi konusunda sesin iletimi konusuyla birlikte, sesin oluşumu ve sesin yansıması konularına göre daha başarılı oldukları ve öğrencilerin öğretilmek istenen kazanımların çoğunu öğrendikleri belirlenmiştir.

Öğrencilerin sesin yansıması konusundaki görsel ve sözel anlama seviyelerinden yola çııılarak tespit edilen zihinsel modellerine bakıldığında, büyük bir kısmının BM kodlu zihinsel modele sahip oldukları görülmüştür. Sesin yansıması konusunda tespit edilen bu zihinsel model yüzdeleri sesin oluşumu, iletimi ve işitilmesi konuları arasında ortalama bir değere sahiptir. Sesin yansıması konusunda öğrenci zihinsel modellerinin tespiti sonucu öğrencilerin sahip oldukları zihinsel modellerin özgün olduğu ve öğrencilerin derslerde kullanılan benzetimlerden etkilendikleri saptanmış ve bu durumun alan yazında yer alan bazı çalışmalarla (Çökelez ve Yalçın, 2012; Yıldız, 2006) benzerlik gösterdiği belirlenmiştir.

İlköğretim sekizinci sınıf öğrencilerinin ses konularında sahip oldukları genel zihinsel modele bakıldığında (bkz. Tablo 8) BM kodlu zihinsel model sınıflandırmasına sahip öğrencilerin çoğunluğu oluşturduğu tespit edilmiştir. Bu durumdan yola çıkılarak öğrencilere verilmek istenilen kazanımların aktarılmasında başarılı olunduğu söylenebilir. Bu anlamda MEB ders kitapları temelinde tasarlanan öğrenme ortamlarının yeterli olduğu ifade edilebilir. Öğrencilerin görsel sorulara verdikleri cevaplarda ağırlıklı olarak günlük hayatta gördükleri durumlardan ve çevrelerinde gerçekleşen olaylardan faydalandıkları görülmüştür. Bu durumdan yola çıkılarak öğrencilerin ses konusunda ki zihinsel 
modellerinin büyük kısmını çevreleri ile olan etkileşimlerinden faydalanarak oluşturdukları ya da değiştirdikleri sonucuna varılmıştır. Ses konusundaki alt başlıklardan hareketle konunun geneline bakıldığında, öğrencilerin ses konusunda sahip oldukları zihinsel modellerinin, bilimsel bilgiler ile uyumlu olduğu ve okul bilgilerinin yeterli olduğu sonucuna varılmıştır. Öğrencilerin çoğunluğunun incelenen kapsamındaki ve yaklaşımdaki konuları yeteri kadar kavrayabilmiş ve zihinlerinde yapılandırmışlardır. Bu çalışmayla, katılımcı öğrencilerin zihinsel modellerinin çoğunu günlük hayattan benzetmelerle yapılandırdıkları, derslerde kullanılan benzetimlerden etkilendikleri ve okul bilgisiyle örtüşen özgün zihinsel modeller oluşturdukları sonucu ifade edilebilir.

\section{5. ÖNERILLER}

Yapılan çalışmada bazı öğrencilerin sesin katı, sıvı, gaz ve boşlukta oluşumu hakkında sözel bilgilerinin eksik olduğu ve görsel sorulara vermiş oldukları cevapların, sözel karşılıklarını bilmedikleri tespit edilmiştir. Bu sebeple öğretmenlerin, sesin farklı ortamlarda oluşumu hakkında öğrencilerin sözel bilgilerini artıracak ders içi etkinliklere daha fazla yer vermesi gerektiği düşünülmekte ve önerilmektedir. Sesin iletimi konusunda öğrencilerin görsel/sözel anlama seviyeleri yüksek oranlarda ve birbirine yakın oldukları tespit edilmiştir. Bu durumdan yola çıkılarak öğretmenler, ders içinde öğrencilerin bilgilerini günlük hayatlarına taşıyabilecekleri etkinliklere yer verebilirler. Ayrıca öğretmenler sesin iletimi konusundaki öğrenci zihinsel modellerinin yüksek oranda olması durumundan faydalanarak sesin diğer alt konularında da benzer ders içi etkinlikler planlayabilirler. Sesin işitilmesi konusunda öğretmenler, öğrencilerin görsel bilgilerini daha da ileri noktalara taşıyacak görsel ve sözel açıklamaları bütünleştiren zengin etkinlikler planlamalıdırlar. Sesin yansıması konusunda öğrencilerin sözel bilgileri diğer alt konulara göre daha yetersizdir. Bu durumu gidermek için öğretmenler tarafından öğrencilerin sözel bilgilerini artıracak farklı nitelikte ders içi etkinliklere yer vermesi önerilmektedir. $\mathrm{Bu}$ anlamda öğrencileri sözel açıklamalar yapmaya yönlendirecek tartışma, beyin firtınası gibi farklı öğretim tekniklerinin kullanılmasının yararlı olacağı düşünülmektedir. Ayrıca kitap yazarları, sesin yansıması konusundaki öğrenci sözel bilgilerini artıracak ifadeleri kavram haritaları, anlam çözümleme tabloları, balık kılçı̆̆ı gibi özetleyen ve ifade etmeyi kolaylaştıran tekniklerin kullanımına daha fazla yer verebilirler.

Ulaşılan sonuçlardan hareketle ses konusundaki genel zihinsel modellere bakıldığında, öğretmenlerin ve kitap yazarlarının GBM, SBM ve UM sahip öğrencilerin eksik algılamalarını tamamlayıcı nitelikte (özellikle görseller ile sözel/metin açıklamalar arasındaki ilişkiyi yansıtacak şekilde) içeriklere daha çok yer vermesi önerilmektedir. Ayrıca, bu çalışma sürecinde edinilen deneyimlere dayalı olarak, bu konu alanında çalışacak araştırmacılara ses konusundaki zihinsel model tespit çalışmalarını farklı öğretim kademelerine taşımaları ve çoktan seçmeli testler gibi farklı veri toplama araçlarıyla öğrenci zihinsel modellerinin nasıl ortaya çıkarılabileceğine yönelik çalışmalar yürütmeleri önerilmektedir. 


\section{KAYNAKLAR}

Atasoy, Ş., Tekbıyık, A. \& Gülay, A. (2013). Beşinci sınıf öğrencilerinin ses kavramını anlamaları üzerine kavram karikatürlerinin etkisi. Türk Fen Eğitimi Dergisi, 10(1), 176-196.

Ayvacı, H. Ş. \& Bakırcı, H. (2018). Farklı öğrenim kademelerindeki öğrencilerin ses konusundaki kavramsal gelişimlerinin incelenmesi. Öğretim Teknolojileri ve Öğretmen Ĕgitimi Dergisi, 7(1), 1-17.

Barman, C. R. \& Miller, J. A. (1996). Two teaching methods and students' understanding of sound, School Science and Mathematics, 2, 63-67.

Beaty, W. J. (2000). Children's misconsepts about science-a list compiled by the aip operation physics project. http://www.amasci.com/miscon/opphys.html

Birinci, O. \& Apaydın, Z. (2016). Modellemeye dayalı öğretimin 4. sınıf öğrencilerinin ses konusundaki kavramsal gelişimine etkisi. Uluslararası Türk Eğitim Bilimleri Dergisi, 2016(7), 22-43.

Bolat, M. \& Sözen, M. (2012). İlköğretim öğrencilerinin sesin hızı ile ilgili sahip oldukları kavram yanılgılarının ve bilgi düzeylerinin belirlenmesi. 10. Ulusal Fen Bilimleri ve Matematik Eğitimi Kongresi, 27-30 Haziran, Niğde.

Bozdemir-Yüzbaşığlu, H., \& Sarıkaya, R. (2019). Mikroskobik canlılar konusunda model tabanlı öğrenme yaklaşımının öğrencilerin zihinsel model gelişimine etkisi. Kalem Eğitim ve İnsan Bilimleri Dergisi, 9(2), 357-384.

Chi, M. T. (2013). Two kinds and four sub-types of misconceived knowledge, ways to change it, and the learning outcomes. In International handbook of research on conceptual change (pp. 61-82). Routledge.

Çepni, S. (2007). Araştırma ve proje çalışmalarına giriş. Trabzon: Celepler Matbaacılık.

Çökelez, A. \& Yalçın, S. (2012). İlköğretim 7. sınıf öğrencilerinin atom kavramı ile ilgili zihinsel modellerinin incelenmesi. Illköğretim Online, 11(2), 452-471.

Dedetürk, A., Kırmızıgül, A. S. \& Kaya, H. (2020). "Ses" konusunun stem etkinlikleri ile öğretiminin başarıya etkisi. Pamukkale Üniversitesi Eğitim Fakültesi Dergisi, 1-28.

Demirci, N. \& Efe, S. (2007). İlköğretim öğrencilerinin ses konusundaki kavram yanılgılarının belirlenmesi, Necatibey Eğitim Fakültesi Elektronik Fen ve Matematik Ĕgitimi Dergisi, 1(1), 23-56.

Demircioğlu, H., Vural, S. \& Demircioğlu, G. (2013). Üstün yetenekli öğrencilerin zihinsel modelleri: maddenin tanecikli yapısı. Eğitim Bilimleri Dergisi, 38, 65-84.

Efe, S. (2007). Üç aşamalı soru tipi geliştirerek ilköğretim beşinci sınıf öğrencilerinin ses konusundaki kavram yanılgılarının belirlenmesi. Yüksek Lisans Tezi, Balıkesir Üniversitesi, Balıkesir.

Eshach, H., \& Schwartz, J. L. (2006). Sound Stuff? Naïve materialism in middle-school students' conceptions of sound. International Journal of Science Education, 28(7), 733-764.

Gilbert, J. K. (2005). Visualization: A metacognitive skill in science and science education. John K. Gilbert (Ed.), Visualization in science education içinde (s. 43-60), Dordrecht: Springer.

Glas, E. (2002). Klein's model of mathematical creativity. Science and Education, 11, 95-104.

Greca, I. M. \& Moreira, M. A. (2002), Mental, physical, and mathematical models in the teaching and learning of physics, Science Education 85(6), 106-121.

Gobert, J. D. ve Buckley, B. C. (2000). Introduction to model-based teaching and learning in science education. International Journal of Science Education, 22(9), 891-894.

Gök Altun, D. (2006). Çoklu zekâ kuramına göre hazırlanmış ses ve ışı ünitesinin öğrenci başarısına, hatırlama düzeylerine, fen bilgisine karşı tutumlarına ve öğretmen ve ögrenci Görüşlerine etkisi. Yayınlanmamış Yüksek Lisans Tezi, Muğla Üniversitesi, Muğla.

Gölgeli, D. \& Saraçoğlu, S. (2011). Fen ve teknoloji dersi "Işık ve Ses" ünitesinin öğretiminde kavram karikatürlerinin kullanımının öğrencilerin akademik başarısına etkisi. Erciyes Üniversitesi Sosyal Bilimler Enstitüsü Dergisi, 31(2), 113-124.

Günbatar, S. \& Sarı, M. (2005). Elektrik ve manyetizma konularında anlaşılması zor kavramlar için model geliştirilmesi, Gazi Eğitim Fakültesi Dergisi, 25(1), 185- 197. 
Güneş, M. H. \& Çelikler, D. (2010). The investigation of effects of modelling and computer assisted instruction on academic achievement. The International Journal of Educational Researchers, 1(1), 20-27.

Gümüş, İ., Demir, Y., Koçak, E., Kaya, Y. \& Kırıcı, M. (2008). Modelle öğretimin öğrenci başarısına etkisi. Erzincan Eğitim Fakültesi Dergisi, 10(1), 65-90.

Harrison, A. G. ve Treagust, D. F. (1996). Secondary students' mental models of atoms and molecules: Implications for teaching chemistry. Science Education, 80(5), 509-534.

Harrison, A. G. ve Treagust, D. F. (2000). A typology of school science models. International Journal of Science Education, 22(9), 1011-1026.

Hestenes, D. (2006). Notes for a modeling theory of science, cognition and instruction. Proceedings of the 2006 GIREP Conference on Modeling in Physics and Physics Education. University of Amsterdam.

Hrepic, Z. (2002). Identifying students' mental models of sound propagation. (Unpublished master's thesis). Kansas State University, Manhattan, Kansas

Hubber, P. (2006). Year 12 students' mental models of the nature of light. Research in Science Education, 36(4), 419-439.

Ingham, A. M. ve Gilbert, J. K. (1991). The use of analogue models by students of chemistry at higher education level. International Journal of Science Education, 13, 193-202.

İyibil, Ü. (2010). Farklı programlarda öğrenim gören öğretmen adaylarının temel astronomi kavramlarını anlama düzeylerinin ve ilgili kavramlara ait zihinsel modellerinin analizi. Yayınlanmamış Yüksek Lisans Tezi, Karadeniz Teknik Üniversitesi, Trabzon.

İyibil, Ü. \& Sağlam Arslan, A. (2010). Fizik öğretmen adaylarının yıldız kavramına dair zihinsel modelleri, Necatibey Ĕgitim Fakültesi Elektronik Fen ve Matematik Eğitimi Dergisi, 4(2), 25-46.

Jong, O.D. (2009). How to teach scientific models and modelling: A study of prospective chemistry teachers' knowledge base, International Journal of Science Education, 31(6), 829-850.

Karamustafaoğlu, S., Bacanak, A., Değirmenci, S. \& Karamustafaoğlu, O. (2010). Ses kavramına yönelik bir çoklu zeka etkinliği. Batı Anadolu Eğitim Bilimleri Dergisi (BAED), 1(2), 130-144.

Kistak, Ö. (2014). İlköğretim 8. sinlf fen ve teknoloji dersi ses ünitesinin yaşam temelli yaklaşımla öğretimi. Yayınlanmamış Yüksek Lisans Tezi, Balıkesir Üniversitesi, Balıkesir.

Kömürkaraoğlu, S. (2011). İlköğretim 6. sinlf fen ve teknoloji dersi ışılk ve ses ünitesinin öğretiminde işbirlikli ögrenme yönteminin öğrenci başarısına ve bilgilerin kalıcllk düzeylerine etkisi. Yayınlanmamış Yüksek Lisans Tezi, Kastamonu Üniversitesi, Kastamonu.

Kurnaz, M. A. (2011). Enerji konusunda model tabanlı öğrenme yaklaşımına göre tasarlanan öğrenme ortamlarının zihinsel model gelişimine etkisi. Yayınlanmamış Doktora Tezi, Karadeniz Teknik Üniversitesi, Trabzon.

Kurnaz, M. A. \& Değermenci, A. (2012). 7. Sınıf öğrencilerinin güneş, dünya ve ay ile ilgili zihinsel modelleri. Ilköğretim Online, 11(1), 137-150.

Kurnaz, M. A. \& Emen, A. Y. (2013). Mental models of the high school students related to the contraction of matter. International Journal of Educational Research and Technology, 4(1), 1-5.

Kurnaz, M. A. \& Emen, A. Y. (2014). Student mental models related to expansion and contraction. Acta Didactica Napocensia, 7(1), 59-68.

Küçüközer, A. (2009). Fen bilgisi öğretmen adaylarının ses konusundaki kavram yanılgılarının incelenmesi. Ilköğretim Online, 8(2), 313-321.

Linder, C. J. \& Erickson, G. L. (1989). A study of tertiary physics students' conceptualizations of sound, International Journal of Science Education, 11, 491- 501.

MEB (2018). Fen bilimleri dersi öğretim programı (İlkokul ve Ortaokul 3, 4, 5, 6, 7 ve 8.Sınıflar). Ankara: Millı Eğitim Bakanlı̆̆ Temel Eğitim Genel Müdürlüğ̈̈̈.

Merino, M. J. 1998. Comlexity of pitch and timbre concepts. Physics Education, 33 (2), 105-109.

National Research Council (1996). National science education standards. Washington, DC: National Academy Press. 
Nersessian, N.J. (1995). Should physicists preach what they practice? Constructive modeling in doing and learning physics. Science and Education, 4, 203-226.

Okur, M. (2009). Kavramsal değişimi sağlayan farklı metotların karşılaştırılması: sesin yayılması konusu örneği, Yayınlanmamış Yüksek Lisans Tezi, Karadeniz Teknik Üniversitesi, Trabzon.

Önen, F., (2005). İlköğretimde basınç konusunda öğrencilerin sahip olduğu kavram yanılgılarının yapılandırmacı yaklaşımla giderilmesi. Yüksek Lisans Tezi, Marmara Üniversitesi Eğitim Bilimleri Enstitüsü, İstanbul.

Öztürk, N. \& Atalay, N., (2012) Öğretmen adaylarının ses konusundaki kavram yanılgılarının incelenmesi. Inönü Üniversitesi Eğitim Fakültesi Dergisi, 13(1), 43-58.

Sağlam Arslan, A., \& Devecioğlu, Y. (2010). Student teachers' levels of understanding and model of understanding about Newton's laws of motion. Asia-Pacific Forum on Science Learning and Teaching, 11(1), Article 7.

Salgut, B., (2007). İlkögrretim 5. sınıffen ve teknoloji dersi ışık ve ses ünitesinde internetin de kullanıldı̆̆ bilgisayar destekli ögretimin öğrenci başarısına etkisi, Yayınlanmamış Yüksek Lisans Tezi, Çukurova Üniversitesi, Sosyal Bilimler Enstitüsü, Adana.

Sözen, M. \& Bolat, M. (2014). 11-18 Yaş öğrencilerin ses hızı ile ilgili sahip oldukları kavram yanılgılarının belirlenmesi. Ondokuz Mayıs Üniversitesi Eğitim Fakültesi Dergisi, 33(2), 505-523.

Stocklmayer, S. (2010). Teaching direct current theory using a field model. International Journal of Science Education. 32 (13), 1801-1828.

Ünal, G. \& Ergin, Ö. (2006). Fen eğitimi ve modeller, Milli Eğitim Dergisi, 171, 188-196.

Vosniadou, S. \& Brewer, W. (1992). Mental models of the earth: A study of conceptual change in childhood, Cognitive Psychology, 24, 535-585.

Vosniadou, S. (1994). Capturing and modelling the process of conceptual change. Learning and Instruction, 4, 4569.

Yıldırım, A. \& Şimşek, H. (2011). Sosyal bilimlerde nitel araştırma yöntemleri. Ankara: Seçkin Yayıncılık.

Yıldız, H. T. (2006). İlköğretim ve Ortä̈ğretim Öğrencilerinin Atomun Yapısı ile İlgili Zihinsel Modelleri. Yayımlanmamış Yüksek Lisans Tezi, Balıkesir: Balıkesir Üniversitesi.

Zeybek, Y. (2007). Sınıf öğretmenliği ögretmen adaylarının kuvvet, hareket ve ses konularında sahip olduklart kavram yanılgılarının tespiti üzerine bir araştırma, Yayınlanmamış Yüksek Lisans Tezi, Gazi Eğitim Bilimleri Enstitüsü, Ankara. 


\section{EK}

EK-1: "Öğrenme Durumların Belirleme Testi (ÖDBT)"'nde bulunan sorulara 310 numaralı öğrencinin verdiği cevaplar ve siniflandırılması.

\begin{tabular}{|c|c|c|}
\hline Soru & 310. Numaralı Öğrenci Cevabı & Cevapların sınıflandırılması \\
\hline 1-Ses nasıl oluşur? Açıklayınız. & Titrespe somicu ducer & Kısmen Doğru Yanlışsız \\
\hline $\begin{array}{l}\text { 2-Sesin nasıl oluştuğuna dair } \\
\text { zihninizdeki görseli/görselleri çiziniz. }\end{array}$ & & Kısmen Doğru Yanlışsız \\
\hline $\begin{array}{l}\text { 3-Katı, sıvı, gaz ve boșlukta sesin } \\
\text { oluşumu farklılık gösterebilir mi? } \\
\text { Açılayınız. }\end{array}$ & & Cevapsiz/Anlamsız \\
\hline $\begin{array}{l}\text { 4-Kat, sıvı, gaz ve boşlukta sesin } \\
\text { oluşumunda farklılıklar } \\
\text { düşünüyorsanız olacağını } \\
\text { görselleyiniz. }\end{array}$ & & Kısmen Doğru Yanlışsız \\
\hline 5-Ses nasıl iletilir? Açıklayınız. & & Kısmen Doğru Yanlışsız \\
\hline $\begin{array}{l}\text { 6-Sesin yayılımını en iyi olacağı } \\
\text { ortamdan (katı, sıvı, gaz ve boşluk) en } \\
\text { kötü olacağı ortama doğru sıralayını. } \\
\text { Sıralamanızın gerekçesini açıklayınız. }\end{array}$ & & Kısmen Doğru Yanlışsız \\
\hline 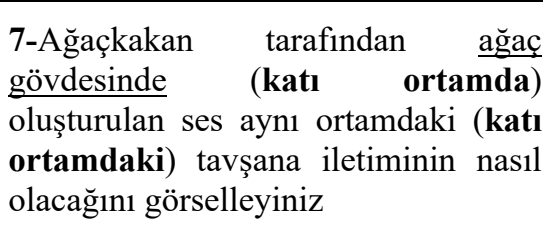 & & Kısmen Doğru Yanlışsız \\
\hline $\begin{array}{l}\text { 8-Fok balığının suyun altında (sıvı } \\
\text { ortamda) oluşturduğu sesi yine aynı } \\
\text { ortamdaki (sıvı ortamdaki) dalgıca } \\
\text { iletiminin } \\
\text { görselleyiniz. }\end{array}$ & 20 & Kısmen Doğru Yanlışsız \\
\hline $\begin{array}{l}\text { 9-Aslanın gaz ortamında kükreyerek } \\
\text { oluşturduğu sesin kendisiyle aynı } \\
\text { ortamdaki tavşana iletiminin nas1 } \\
\text { olacağını görselleyiniz }\end{array}$ & & Kısmen Doğru Yanlışsız \\
\hline 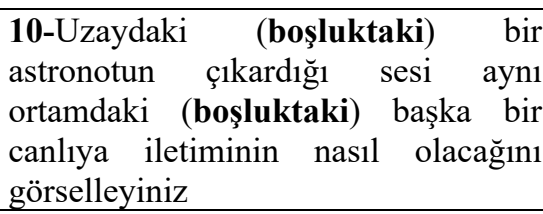 & $\rightarrow \quad m$ & Kısmen Doğru Yanlışsız \\
\hline $\begin{array}{l}\text { 1-Bir ses kaynağından çıkan sesi nasıl } \\
\text { ișitiyoruz? Açıklayanız. }\end{array}$ & Sesi Kulogin & Kısmen Doğru Yanlışsız \\
\hline $\begin{array}{l}\text { 2-Ses kaynağından çıkan sesi nasıl } \\
\text { işittiğimizle ilgili zihninizde oluşan } \\
\text { görseli/görselleri çiziniz. }\end{array}$ & & Kısmen Doğru Yanlışsız \\
\hline
\end{tabular}




\begin{tabular}{|c|c|c|}
\hline 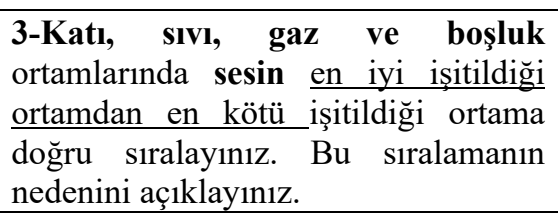 & 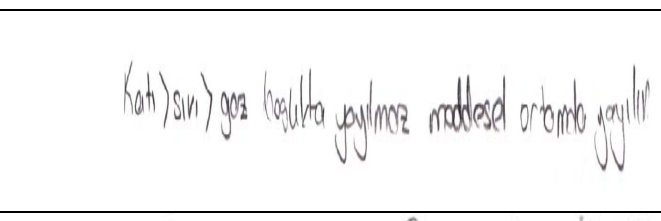 & Kısmen Doğru Yanlışsız \\
\hline $\begin{array}{l}\text { 4-Ses kaynağının uzaklığı işitmemize } \\
\text { etki eder mi? Açıklayınız. }\end{array}$ & 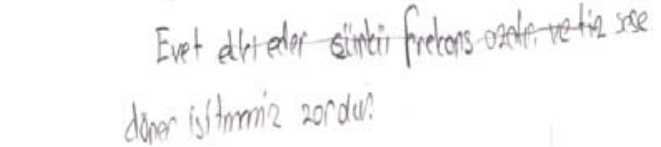 & Kısmen Doğru Yanlışsız \\
\hline $\begin{array}{lcr}\begin{array}{l}\text { 5-Birbiriyle } \\
\text { birbirlerine }\end{array} & \begin{array}{c}\text { konuşan } \\
\text { olan }\end{array} & \begin{array}{c}\text { iki arkadaşın } \\
\text { uzaklıklarının }\end{array} \\
\text { işitmelerine } & \text { etki } & \text { edeceğini } \\
\text { düşünüyorsanız bu } & \text { etkinin nasıl } \\
\text { olacağına } & \text { dair } & \text { zihninizdeki } \\
\text { görseli/görselleri çiziniz. }\end{array}$ & 包 & Kısmen Doğru Yanlışsız \\
\hline 6-Ses yansir mi? & 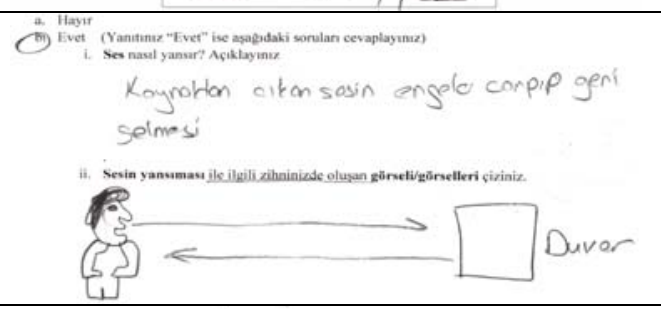 & Yanlış \\
\hline $\begin{array}{l}\text { 7-Sesin katı bir cisimle karşılaştı̆ıında } \\
\text { ne olacağını açıklayınız. }\end{array}$ & $\begin{array}{l}\text { Ses kati bir cisme corptrinot } \\
\text { sess genigelli? }\end{array}$ & Kısmen Doğru Yanlışsız \\
\hline $\begin{array}{l}\text { 8-Sesin katı bir cisimle karşılaş̧tı̆̆ında } \\
\text { ne olacağına dair zihninizdeki görseli } \\
\text { çiziniz. }\end{array}$ & ivar & Kısmen Doğru Yanlışsız \\
\hline $\begin{array}{l}\text { 9-Sesin bir șivıyla karşılaştığında ne } \\
\text { olacağını açıklayınız. }\end{array}$ & 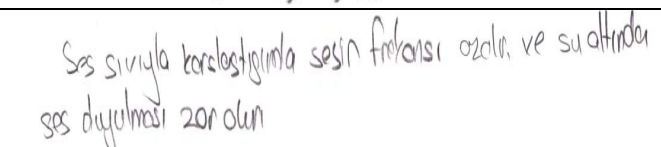 & Yanlış \\
\hline $\begin{array}{l}\text { 10-Sesin bir sıviyla karşılaştığında ne } \\
\text { olacağına dair zihninizdeki görseli } \\
\text { çiziniz. }\end{array}$ & $\left(\begin{array}{c}\sigma_{3} \\
5\end{array}\right)$ & Kısmen Doğru Yanlışsız \\
\hline $\begin{array}{l}\text { 11-Sesin gazla karşılaştı̆ıında ne } \\
\text { olacağını açıklayınız. }\end{array}$ & tir & Kısmen Doğru Yanlışsız \\
\hline $\begin{array}{l}\text { 12-Sesin } \\
\text { olacağla } \\
\text { çizinaz. }\end{array}$ & & Kısmen Doğru Yanlışsız \\
\hline $\begin{array}{l}\text { 13-Sesin boşlukla karşılaşıtı̆ında ne } \\
\text { olacağını açıklayınız. }\end{array}$ & $p \rho z$ & Kısmen Doğru Yanlışsız \\
\hline $\begin{array}{l}\text { 14-Sesin boşlukla karşılaştı̆̆ında ne } \\
\text { olacağına dair zihninizdeki görseli } \\
\text { çiziniz. }\end{array}$ & $x$ & Kısmen Doğru Yanlışsız \\
\hline
\end{tabular}




\section{EXTENDED ABSTRACT}

It seems that learning is more effective in learning environments where mental models are considered. It includes misconceptions, false beliefs, and unscientific mental models. Therefore, it is important to determine the mental models for the concept of sound, in which various alternative ideas are identified. In the study, it was aimed to determine the mental models of the eighth-grade students on the sound subject including 'formation, transmission, hearing, and reflection of the sound', and to reveal the general mental models of the students on the basis of the determined mental models.

The research was conducted in the form of a case study. The research was carried out with a total of 416 eighth grade students in five different schools randomly selected among the schools in the city center of Kastamonu. In the development of the data collection tool, the acquisitions on the subject of sound were examined in detail in the science education curriculum. At the next stage, how mental models were revealed or identified in the relevant literature was investigated. Based on the views of the curriculum and the field expert, "Test for determining learning situations (TDLS)" was prepared. The questions were finalized considering the analyses and expert opinions made after the pilot study. A total of 25 questions were prepared, including four from the formation of sound, six from its transmission, five from its hearing and ten from its reflection. In the end, a data collection tool consisting of 25 questions on the sound subject has been developed.

During the analysis of the answers given to the questions in TDLS, the answers given by 416 students to the questions were analyzed in two separate groups, verbal and visual. Understanding levels were determined separately for the students' visual/verbal responses to the formation, transmission, hearing and reflection of sound. Then, student mental models were revealed based on the levels of visual and verbal understandings for each sub-subject. The mental models of the students were classified as "Scientific Model (SM), Visual Dominant Model (VIDM), Verbal Dominant Model (VEDM) and Incompatible Model (IM)". The determination of the mental models was carried out independently for each sub-subjects. The 'General Mental Models (GMM)' about the sub-subjects of sound were determined based on the mental models that the students had in the subjects of the formation, transmission, hearing and reflection of sound. After the mental models of the students were determined about the sound subjects, GMMs were found according to the relevant scoring criteria. The students' GMMs were classified as scientific models if they were between 2.34 and 3.00, synthesis Model if they were between 1.66 and 2.33, and primitive Model if they were between 1.00 and 1.65.

The answers given by the students for each question related to the formation, transmission, hearing, and reflection of the sound in the TDLS were analyzed independently. More than half (59.62\%) of students have SM, about a quarter (22.11\%) have VIDM and very few have a VEDM (10.1\%) or IM $(8.17 \%)$ mental model, when it comes to sound formation. As for the transmission of sound, it is understood that a very large proportion $(81.97 \%)$ of students have an SM, some $(10.82 \%)$ have a VIDM and a very small number have an IM (5.05\%) or a VEDM (2.16\%) mental model. About hearing the sound, it appears to have a mental model that most of the students $(81.97 \%)$ have SM, some $(15.15 \%)$ have VEDM and a few have VIDM (1.68\%) or IM (1.2\%). As for the reflection of sound, it is observed that a very large proportion of students $(76.93 \%)$ have an SM mental model. However, students were found to have VEDM (8.89\%), VIDM (7.93\%) and IM (6.25\%) mental model. Based on the students 'mental models on the sub-subject of sound, the students' general mental models of sound were determined. Among the overall mental models related to the sound subject, the largest percentage is $82.93 \%$ belonging to the scientific model. The synthesis model percentage is $14.67 \%$ while the primitive model percentage is $2.4 \%$. It has been found that there is a large difference between scientific model

Anadolu Üniversitesi Ĕ̆itim Fakültesi Dergisi (AUJEF), 4(3), 254-275 
percentage and synthesis and primitive model percentages. Depending on this situation, it can be said that it was successful in transferring the learning outcomes. Based on the results, it is suggested that teachers and book writers should include more content that complements the incomplete perceptions of students with VIDM, VEDM and IM (especially, by reflecting the relationship between visuals and verbal/textual explanations). In addition, based on the experience gained in this study process, researchers are recommended to carry their mental model determination studies on sound to different teaching levels and to conduct studies on how to reveal student mental models with different data collection tools such as multiple-choice tests 